\title{
Impact Assessment of INR Crunch on Grocery Shops of Phuentsholing (Bhutan)
}

\author{
Pawan Kumar Sharma ${ }^{1}$ \\ Correspondence: Pawan Kumar Sharma, Principal, Dyal Singh College (E), University of Delhi; was on \\ deputation to Royal University of Bhutan from 2010-2014 under TCS of Colombo Plan, Ministry of External \\ Affairs, Govt. of India. E-mail: drpawankumar1958@rediffmail.com
}

Received: June 19, 2015 Accepted: November 11, 2015 Online Published: November 30, 2015

doi:10.5539/ass.v11n28p240 URL: http://dx.doi.org/10.5539/ass.v11n28p240

\begin{abstract}
Present study explores impact of INR crunch on grocery shops in Phuentsholing, commercial nerve centre of Bhutan. To study impact of Indian National Rupee crunch, it attempts to find out effects with regard to change in sales, profitability, and trading practices of grocery shops. Bhutanese perceived that prices of commodities were triggered by rupee crunch. It attempts to verify whether prices of commodities were really affected by rupee crunch.

Since, number of grocery shops in Phuentsholing town is meager; the sample size for research is whole population. Data were collected from all 34 grocery shops through distribution of questionnaires and, to gauge the situation prior to rupee crunch, interviews were also conducted. Data collected were analyzed with the appropriate statistical tools.
\end{abstract}

\section{Introduction}

In early 2012, the INR (Indian National Rupee) crunch stories went viral across Bhutan in electronic and print media. To begin with, people overlooked it as something which would bother only the government and central bank. The shortage of INR affected all sectors of economy and, in due course, was felt even in remote parts of the Himalayan Kingdom. As per few reports, Bhutan's capacity to import essential commodities was slowly being pinched. Ngultrum (Bhutanese currency) was being devalued against INR across border towns as some Indian businessmen demanded extra if paid in ngultrum. The businessmen and general public were concerned at rise in essential commodities prices over a short period. For imports, Bhutan is highly dependent on India as it procures almost all essential commodity needs from it. The sudden INR scarcity impacted import of essential grocery items leading to cost escalation and triggered price rise.

\section{Objective, Scope and Hypothesis}

The objective and scope of present study is to assess impact of INR crunch on price rise of groceries, trading practices, sales and profitability; on grocery shops in Phuentsholing, commercial nerve centre of Bhutan. The relationship between 'Rupee crunch and change in consumption pattern of customers' has been studied with following hypothesis/alternative hypothesis:

$\boldsymbol{H}_{\boldsymbol{o}}$ : The rupee shortage has led to change in consumption pattern of people.

$\boldsymbol{H}_{1}$ : The rupee shortage has not led to change in consumption pattern of people.

\section{Literature Review}

The rupee crunch can be defined as classic demand-supply logic - supply of rupees has not been able to keep pace with demand for rupees (Bisht, 2012). High public expenditure and auxiliary sector growth to support hydropower development, private sector growth led to expansion of credit mainly in housing, manufacturing and service sectors and private spending on health, education, increasing pilgrimages and students studying in India, remittances by Indian workers, increase in number of vehicles and fuel import, inappropriate cross border trade practices are some causes which triggered rupee shortage (Task Force report, 2012).

On supply side, limited export base and slow export growth, limited foreign direct investment also impacted rupee situation. Bhutan's current rupee shortfall is a consequence of balance of payment with India on account of trade in goods, services and net sum of all capital and financial transactions. Indian Assistance of budgetary, 
hydropower-related grants and loans helped finance trade and maintain balance of payment surplus over past years resulting in gradual accumulation of rupee reserves. However, tremendous growth in import of goods and services from India resulting in lower rupee earnings resulted in decrease of rupee reserves and current shortfall. Bhutan's trade deficit had been growing steadily and faced current account deficit (Task Force Report, 2012). Any economy to be sound should have favorable trade balance (Kinzang Norbu, 2012). Rupee-crunch was occasioned by poor fiscal policies and mismanagement of economic affairs caused by economic dependence on India, sustained by growing economic ties between two countries (Medha Bisht, 2012).

With rupee crunch upsurge, Bhutanese realized rupee is also foreign currency such as Dollars, Euros and Pounds. Although, end customers pay ngultrum; dealers and distributors pay INR to import. With increasing consumption over the years, the demand for INR increased year after another until such time when credit limit reached the maximum (Norbu, 2012). Bhutan stopped considering rupee as legal tender and not available for free circulation. The Royal government and RMA agreed to allow payment for rupee imports for select essential products by rationing the rupee one can withdraw for personal use and business transaction were streamlined (Daw Tenzin, Governor, RMA). Bhutan perhaps faced an economic problem which could lead to crisis if appropriate measures were not taken with rupee shortage reaching unprecedented levels threatening to hold Bhutanese economy to ransom.

With RMA deciding to stop rupee replenishment for commercial banks, certain sectors in country felt the pinch. Economists claimed, economic activities will be brought to standstill given volume of trade with India particularly essential commodities. Enforcing stringent rules for business transactions and rationing of rupee was bound to impact business operations and hamper grocery business in particular due to high dependency on Indian imports. Almost, 60- 70 percent essential commodities come from India, as per director general of trade. Every month, Food Corporation of Bhutan (FCB) alone imported rice, vegetable oils and sugar from India worth Rs 35 - 40 million. FCB's inability to make timely payments might directly affect essential commodities availability. If there is no rupee, everything will stop.

In far-flung villages of Haa and Samtse Dzongkhags, rupee shortage was manifested in prices of essential goods imported from India rising. In places where radio is the only means of staying connected with rest of the country, people were increasingly feeling ripples as prices of essential goods almost doubled during INR shortage, said Sonam Pelden of Business Bhutan. Ugyen Tshering, a shop owner of Sambaykha in Haa said with rising prices, he stopped selling lot of products. If he procures products at prevailing prices nobody buys even for 1-2 ngultrum margin. Further, businessmen of bordering towns did not accept ngultrum, when they accepted they charged extra, said Mochu Mangmi of Samdrup Zongkhar.

\section{Methodology}

It is an exploratory survey with descriptive and analytical research. Both primary and secondary data have been used to gather necessary information - primary data collection includes the questionnaires designed to study effect of crunch on grocery shops and structured interview is done to know situation prior to eruption of crunch. To support primary data, relevant information has been collected through secondary data such as Internet, Journals, Magazines and Newspapers. Questionnaires distributed to and interviews were conducted with all 34 grocery shop owners of Phuentsholing to obtain more information. Hence, whole population were respondents. The data were analyzed using SPSS version 19, MS-Excel and simple frequencies like percentages and cross tabulation etc. Tables have also been used to make final output and explanation clear.

\section{Findings and Analysis}

Taking various parameters like impact on grocery business, procurement sources, changing suppliers, procurement frequency, currency for payment, consumption pattern changes, sales, profitability and costs, price rise, business sustenance strategies employed etc have been studied to test the hypothesis.

1. Impact on grocery business: Most Bhutanese perceived an immense negative impact of rupee crunch on essential commodities and on grocery business. From Table 1, it was clear that $9 \%$ respondents experienced the impact of crunch immensely, $23 \%$ moderately and $15 \%$ up to certain extent. While $21 \%$ respondents did not feel any impact and $32 \%$ were affected the least. Since, maximum number (27 out of 34 ) felt impact of INR shortage minutely or immensely. It can be concluded the rupee crunch affected the grocery business. 
Table 1. Rupee Crunch Impact on Grocery Business

\begin{tabular}{ccc}
\hline Impact & No. of Respondents & $\%$ \\
\hline Very Much & 3 & 9 \\
Somewhat & 5 & 15 \\
Moderate & 8 & 24 \\
Least & 11 & 32 \\
Not at all & 7 & 21 \\
& $\mathbf{3 4}$ & $\mathbf{1 0 0}$ \\
\hline
\end{tabular}

Table 2. Country of Procurement and INR crunch

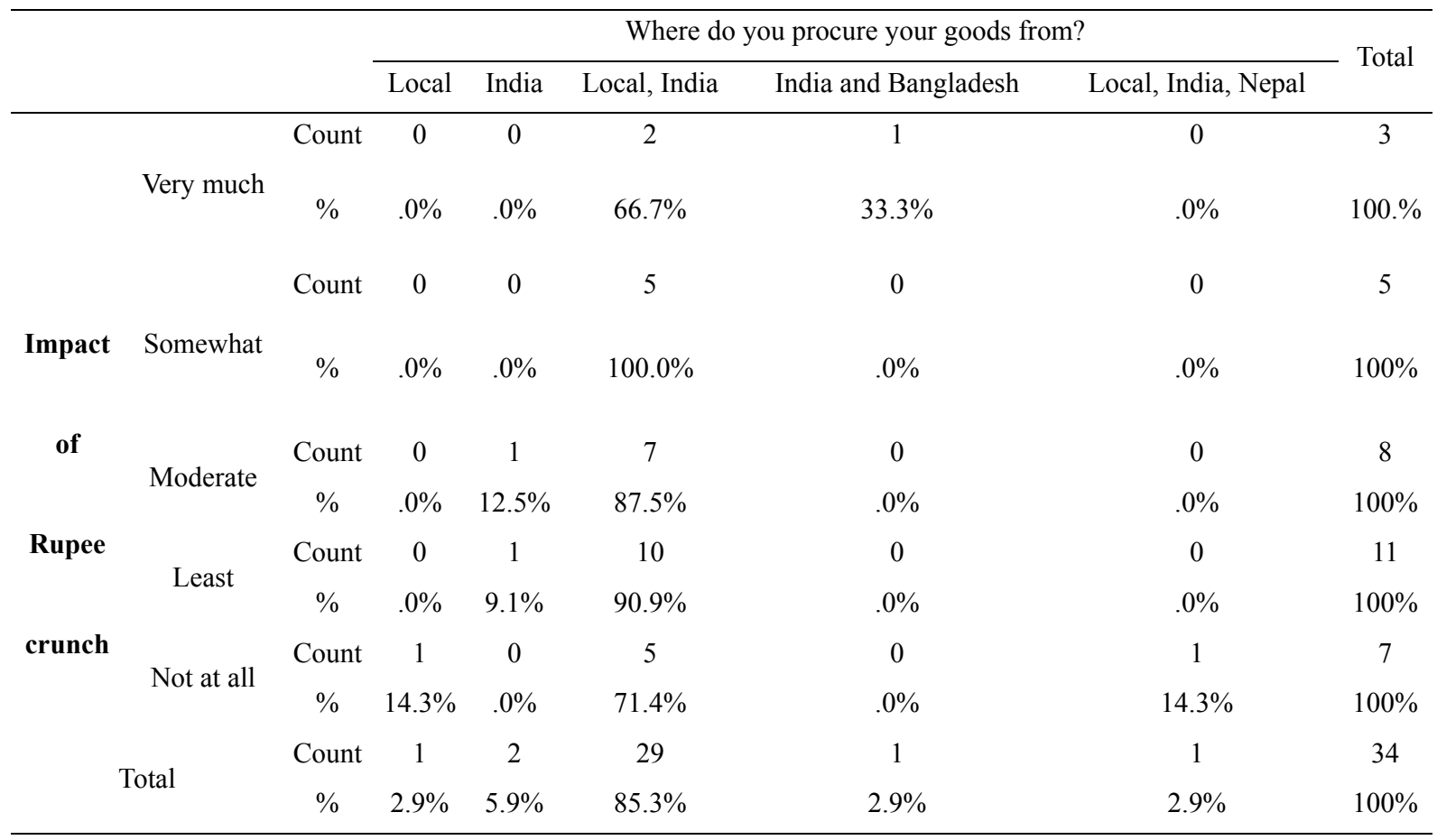

As per cross tabulation Table 2 between place / country of procurement of groceries and extent of rupee crunch impact; it did not impact who procured indigenously. The grocery businessmen procuring from Indian suppliers as well as third countries were hardest hit. However, who procured from both Indians and local stores experienced moderate heat.

2. Grocery procurement sources: Phuentsholing grocers procured from different suppliers based in neighboring countries. Most grocery items were bought from India and local stores, Table 3. Barring two (6\%) grocery shop owners importing from third countries i.e. one (3\%) from Bangladesh and another (3\%) from Nepal. The reasons for purchasing major portion of essential commodities from India and local stores are transportation costs followed by difference in prices. In the crunch aftermath, retailers in third countries did not hold an account to avail demand draft policy.

Table 3. Procurement sources

\begin{tabular}{ccc}
\hline Suppliers based Countries & Respondents & $\%$ \\
\hline Local & 31 & 91 \\
India & 33 & 97 \\
Bangladesh & 1 & 3 \\
Nepal & 1 & 3 \\
\hline
\end{tabular}


As per cross tabulation Table 4, there is one who procures wholly locally, two of them exclusively from Indian suppliers, 29 grocers procure both locally as well as from India. Two grocers in Phuentsholing, however, procure from Indian suppliers and third countries.

Table 4. Country/place of Procurement

\begin{tabular}{cccccc}
\hline & & \multicolumn{3}{c}{ Currency for Payment } \\
\cline { 3 - 5 } Country/ Place of Procurement. & Local stores & 1 & 0 & 0 & 1 \\
& & Ngultrum & INR & Nu. and INR \\
& Local and India & 0 & 2 & 0 & 2 \\
& India and Bangladesh & 0 & 1 & 0 & 1 \\
& Local, India and Nepal & 0 & 0 & 1 & 1 \\
& & & 3 & 30 & 34 \\
\hline
\end{tabular}

3. Change of suppliers following rupee crunch: Most Phuentsholing grocers import all/majority from India and few from countries like Nepal and Bangladesh. Owing to INR non-availability, trading practices viz. import quantity, place/country of procurement, procurement times etc of these traders were changed. For instance, few started major procurement from local stores instead of India. Four grocery shop owners (12\%), in Phuentsholing town, changed suppliers due to crunch; however, 30 respondents $(88 \%)$ remained unchanged, Table 5.

Table 5. Change in suppliers due to crunch

\begin{tabular}{ccc}
\hline Responses & No. of Respondents & Percentage $\%$ \\
\hline Yes & 4 & 12 \\
No & 30 & 88 \\
Total & 34 & 100 \\
\hline
\end{tabular}

As per cross tabulation between change of grocery suppliers and country/place of procurement these four grocery shop owners were who earlier imported from India. Some Indian suppliers were unable to provide original invoice to importers, a must to avail demand draft facility. These importers started purchasing mostly from local stores due to lack of INR and escalation of transportation costs. However, those sticking to same suppliers stated, 'we get original invoice which facilitates payment by demand draft and receive concessions'.

4. Monthly procurement frequency: The grocery shop owners procure/import economic size quantity from suppliers at varying intervals. It depends on sales and procurement capacity. The gathered data indicate changes in procurement cycle. Lowest number of procurements by Phuentsholing grocers are one to three times a month and maximum up to ten and above times. There were not many changes in procurement numbers, Table 6 . However, number of grocers procuring ten times and above in a month increased from $26 \%$ before rupee crunch to $29.6 \%$ afterwards. Procurement numbers went up as sales increased due to more customers in Phuentsholing.

Table 6. Monthly Procurement Frequency

\begin{tabular}{ccc}
\hline Procurement Frequencies & Before & After \\
\hline 1 to 3 & $29 \%$ & $29.4 \%$ \\
4 to 6 & $32 \%$ & $29.4 \%$ \\
7 to 9 & $12 \%$ & $11.8 \%$ \\
10 and above & $26 \%$ & $29.4 \%$ \\
\hline
\end{tabular}


5. Currency of payment: Prior to rupee shortage outburst, payments to suppliers in Indian bordering towns could be made in ngultrum or INR; not compulsory for buyers/ importers to pay in INR. As per survey, $88 \%$ paid suppliers in ngultrum while $97 \%$ in rupee, Table 7. All grocery sellers, procuring from India and third countries, paid in INR by availing demand draft facility. However, those procuring locally did not need to pay in rupee. Our study indicates, higher number of grocers paid in rupee as they procured small or higher quantity from India and third countries.

Table 7. Currency of Payment

\begin{tabular}{ccc}
\hline Currency & No. of respondents & $\%$ \\
\hline Ngultrum & 30 & 88 \\
INR & 33 & 97 \\
\hline
\end{tabular}

According to cross tabulation results between currency of payment and procurement country, 88\% (30 respondents) paying in ngultrum were who procured few grocery items from local stores such as Tashi Commercial Corporation and Damchen Agencies. On the other hand, 97\% (33 respondents) procuring from India and third countries paid in INR. Obviously, there is one shop which procures everything from local stores while four do not purchase even single grocery locally.

6. Changes in consumption pattern: Few grocers have observed changes regarding quantity and quality of essential commodities being bought by regular customers. It is purchasing power induced change in consumer behaviour. As per survey results, $24 \%$ grocers said consumption pattern altered due to rupee crunch while 53\% (18 out of 34 ) disagreed and $23 \%$ remained neutral to it, Table 8 .

Table 8. Consumption pattern changes

\begin{tabular}{ccc}
\hline Responses & No. of Respondents. & $\%$ \\
\hline Disagree & 18 & 53 \\
Neutral & 8 & 24 \\
Agree & 8 & 24 \\
\hline Total & 34 & 100 \\
\hline
\end{tabular}

7. Source of procurement: As high as 29 grocery shop owners procure from both Indian suppliers as well as local stores, Table 9. However, those who procure grocery items from both local stores and Indian suppliers, purchase major portion of groceries from Indian suppliers. Therefore, impact of rupee crunch affected the most who procured from both local stores and Indian suppliers.

Table 9. Source of procurement

\begin{tabular}{cc}
\hline Suppliers & No. of respondents \\
\hline Local & 0 \\
India & 29 \\
\hline
\end{tabular}

8. Impact of rupee crunch on Sales, Profitability and Costs: After determining extent of impact of rupee shortage, either positive or negative, we may assess its impact on sales, profitability and costs.

a. Sales: As per Table 10, 29\% grocery sellers' sales increased and unaffected for $47 \%$, on the other hand, for $24 \%$ sales decreased after rupee crunch. $29 \%$ whose sales increased attributed to more customers visiting their shops. The INR shortage compelled buyers to buy from local shops as Jaigaon shops in India did not accept ngultrum, although, few Jaigaon sellers accepted ngultrum but charged 5\% to 10\% extra. As a result, who used to buy from Jaigaon now buy from Phuentsholing shops. This enhanced sales of $29 \%$ Phuentsholing grocery sellers. On the other hand, $24 \%$ grocery sellers said that shortage of INR hampered their purchasing capacity; could not import commodities demanded by customers caused decrease in sales. 
Table 10. Sales

\begin{tabular}{ccc}
\hline Responses & No. of Respondents. & $\%$ \\
\hline Increased & 10 & 29 \\
Normal & 16 & 47 \\
Decreased & 8 & 24 \\
Total & 34 & 100 \\
\hline
\end{tabular}

b. Profitability: Rupee crunch had positive impact on profitability of $27 \%$ while $47 \%$ had no impact and negative impact on $26 \%$ of grocery shop owners, Table $11.26 \%$ grocery sellers whose profits improved mentioned increase in sales as main cause. On the other hand, few said although sales increased but costs also increased and as such profitability remained unaffected while for few rise in costs led to reduction in profits.

Table 11. Profitability

\begin{tabular}{ccc}
\hline Responses & No. of Respondents & $\%$ \\
\hline Increased & 9 & 26.5 \\
Normal & 16 & 47 \\
Decreased & 9 & 26.5 \\
Total & 34 & 100 \\
\hline
\end{tabular}

c. Cost Escalation: After rupee crunch eruption, none of the grocery sellers in Phuentsholing felt positive impact regarding costs, Table 12 . On the contrary, it had massive negative impact whereby costs in case of $62 \%$ grocery sellers escalated. These $62 \%$ stated that main causes for cost escalation were rise in fuel price and loading-unloading charges by porters. Nevertheless, $38 \%$ claimed their cost remained as before.

Table 12. Cost escalation

\begin{tabular}{ccc}
\hline Responses & No. of Respondents & $\%$ \\
\hline Increased & 21 & 62 \\
Normal & 13 & 38 \\
Decreased & 0 & 0 \\
Total & 34 & 100 \\
\hline
\end{tabular}

As per cross tabulation of results between procurement country and costs, costs of grocery shop owners procuring from local stores remained unaffected while from Indian suppliers had escalated. The majority of grocers, $62.1 \%$ (18 out of 29 ) procure from India as well as from local stores; their costs were escalated. In addition, overall costs procuring from Indian suppliers and third countries also rose.

9. Price rise of essential commodities: Most Bhutanese perceived price rise was triggered owing to rupee crunch. However, $79 \%$ stated that rupee crunch is not the main cause, Table 13. Mostly stated price rise depends on demand-supply of grocery items i.e. higher the supply, lower the price and vice versa. Nevertheless, $21 \%$ mentioned rupee crunch led to increase in price.

Table 13. Price rise of essential commodities

\begin{tabular}{cc}
\hline Responses & No. of respondents \\
\hline Yes & 7 \\
No & 27 \\
\hline
\end{tabular}

10. Business sustaining strategies: $8 \%$ managed price rise by analyzing market and fix price taking 
procurement cost into account. But, around 25\%, sold goods at lower profit margins to sustain business. They also resort to bulk purchases directly from Indian manufacturing plants for cost stabilization, import better quality products, and customer relationship management. Moreover, price rise affects all sellers so it is not difficult to retain customers.

Hypothesis Testing: As per Tables 14-15, calculated Pearson Chi-Square value is 2.892 with associated significance level of 0.089 . Since, 0.089 is higher than alpha value of 0.05 , the null hypothesis is rejected, i.e., INR crunch have led to change in consumption pattern of customers and the alternative hypothesis is accepted, i.e., INR crunch have not led to change in consumption pattern of customers. This means no relationship between rupee crunch and consumption pattern is established in our study. Rupee crunch did not affect consumption pattern of Bhutanese.

Table14. Change in consumption pattern and rupee crunch $*$ Cross Tabulation

\begin{tabular}{ccccc}
\hline & \multicolumn{3}{c}{ INR crunch has led to change in consumption pattern of customers } & Total \\
\cline { 2 - 5 } & & Disagree & Agree & \\
\hline \multirow{2}{*}{ Impact of rupee crunch } & moderate & 6 & 10 & 16 \\
Total & least & 12 & 6 & 18 \\
& 18 & 16 & 34 \\
\hline
\end{tabular}

Table 15 .

\begin{tabular}{cccc}
\hline Chi-Square Test & & & \\
\hline & Value & Degree of freedom & Asymp. Sig. (2-sided) \\
Pearson Chi-Square & 2.892 & 1 & .089 \\
\hline
\end{tabular}

\section{Conclusions}

The impact of INR crunch was felt across Bhutan daily as people paid more than usual. Majority of grocery shop owners felt rupee crunch heat although the extent varied amongst them. However, rupee crunch impact was not felt if goods were procured indigenously. Impact was also place of procurement sensitive, importing from Indian suppliers as well as third countries affected more. It affected grocery business positively as well as negatively leading to change in sales levels, overall costs incurred and profitability of grocery shops. To withstand impact, few grocers changed suppliers as well as trading practices.

Groceries in Bhutan are procured mostly from India necessitating rupee. Previously, Ngultrum enjoyed full parity with INR. But, Ngultrum circulation scope in bordering towns was narrowed down in rupee crunch aftermath. The Indian suppliers insisted payments to be in rupee, and if paid in Ngultrum, charged extra per cent on amount payable. To reduce impact, demand draft policy to streamline difference between Ngultrum and Rupee was introduced by the RMA, which is equivalent to cash payment.

In peoples' perception, main cause of rise in grocery prices is rupee crunch. However, in reality it is due to escalation in production cost. Few grocery businesses generated more revenue after INR scarcity as Jaigaon shops demanded rupee, compelling local purchases. The government should strategize reducing dependency on other countries for country's development to be self-reliant. The five year plan should focus sectors to reduce imports. The government can promote more local produce as well as create avenues for exports by giving subsidies to encourage.

\section{Future Direction of Research}

People perceive rupee crunch as main cause of rise in grocery prices. However, prices depend on cost of raw materials required for production. Therefore, to study impact of rupee crunch on other businesses for a comprehensive grasping is necessary. The present study is confined to Phuentsholing town grocery shops and, as such, findings may not be generalized across the nation.

\section{References}

Bisht, M. (2012). The Rupee Crunch and India- Bhutan Economic Engagement. Retrieved from http:/www.idsa.CrunchandIndiaBhutanEconomicEnga160712

Chhetri, P. (2012). Bhutan economy feels the rupee pinch. Retrieved from http://www.bhutanobserver.bt/bhutan- 
economy-feels-rupee-pinch/

Dorji, M. (2012). BCCI study shows that government spending is main cause of rupee crisis. Retrieved from http://www.thebhutanese.bt/bcci-study-shows-that-government-spending-is-main-cause-of-rupee-crisis/

Dorji, P. (2012), Heading from crunch to crisis. Retrieved from http://www.businessbhutan.bt/?p=9153

Gupta, S. C. (2011). Fundamentals of Statistics (6th ed.). Mumbai: Himalaya Publishing House Pvt. Ltd.

Kothari, C. (2008). Research Methodology (2nd ed.). Delhi: New Age International (P) Limited.

Norbu, K. (2012). The Indian Rupee Crunch. Retrieved from http://kinzangnorbu.blogspot.com/2012/03/indianrupee-crunch.html

Pelden, S. (2012). The waves of rupee crunch rock rural villages of Haa. Retrieved from http://www.businessbhutan.bt/?p=9620

Task Force report. (May 11, 2012). Bhutan Chambers of Commerce and Industry. Retrieved from http://www.cabinet.gov.bt/.../Task\%20Force\%20Report $\% 20 \% 20$

Tshering, K. (2012). My take on Rupee Crunch. Retrieved from http://www.ktshering.com/2012/05/mytake-on-rupee-crunch.html

Wangdi, T. (2012). Finance Minister's solution to rupee crisis. Retrieved from http://www.bhutantimes.bt/php? comview\&id=3088\&Itemid

Wangmo, T. (2012). Rupee crunch leads to soaring informal exchange rates in border towns. Retrieved from http://www.thebhutanese.bt/rupee-crunch-leads-to-soaring-informal-exchange-rates-in border-towns/

\section{Copyrights}

Copyright for this article is retained by the author(s), with first publication rights granted to the journal.

This is an open-access article distributed under the terms and conditions of the Creative Commons Attribution license (http://creativecommons.org/licenses/by/3.0/). 